\title{
Carcinogenic trace metals in ground water of Bathinda district, Punjab, India
}

\author{
Kaptan Singh $^{1}$, Govind Pandey ${ }^{2}$, Rajesh Singh ${ }^{3}$ \\ ${ }^{1 *, 2}$ Civil Engineering Department MMMUT, Gorakhpur, India \\ ${ }^{3}$ National Institute of Hydrology, Roorkee, India \\ "Corresponding Author: e-mail: singhkaptan886@gmail.com Tel +91-8006850636 \\ Orcid id: https://orcid.org/0000-0002-6410-4453
}

\begin{abstract}
Water is the second important source for surviving of human being on the earth because of it plays the major role in functioning of the body. in some decades decline the water quality due to the threatening of the environmental conditions and disposed untreated waste water in the water bodies which generate during the different activity in industries and human activities, which causes of increases of contamination of carcinogenic metals Include, mercury, cadmium, Arsenic, chromium, Selenium, Beryllium, Cobalt and nickel in ground water. These toxic metals Cancer causing to human being. Metals found in combined form of other element in the water. Carcinogenic metals $\mathrm{Hg}, \mathrm{Cr}, \mathrm{As}, \mathrm{Co}, \mathrm{Cd}$, etc. also constituents of the earth crust. These were soluble in the percolate water, merged in the ground water. we have Evidences of carcinogens metals in the ground water of Bathinda district of Punjab. The present study attempt has been made to identify the types and concentration of different carcinogenic metallic ions present in ground water of South-Western, Bathinda district of Punjab. The $\mathrm{pH}$ was ranged from 6.5 -7.4 which were within the permissible limit of drinking ground water. $\mathrm{Cr}$ and $\mathrm{Hg}$ is above the permissible limit of drinking water quality guideline of WHO and BIS. Cr ranged from 70-360 ppb in ground water and highest level of $\mathrm{Cr}$ was observed at Lehra Mohabbat. The permissible limit in drinking water of $\mathrm{Hg}$ is $1 \mathrm{ppb}$, all the sample have the $\mathrm{Hg}$ concentration level is above the limit. Expect three sites (JWS2-17.6 ppb, Bhambhia-11.9 ppb and Ganga-10.7 ppb) the concentration of Se and As was below the permissible limit.
\end{abstract}

Keywords: Carcinogenic, Trace Metals, Contamination, Concentration, Ground Water

DOI: http://dx.doi.org/10.4314/ijest.v13i1.16S

Cite this article as:

Singh K., Pandey G., Singh R. 2021. Carcinogenic trace metals in ground water of Bathinda district, Punjab, India. International Journal of Engineering, Science and Technology, Vol. 13, No. 1, pp. 105-111. doi: 10.4314/ijest.v13i1.16S

Received: December 1, 2019; Accepted: February 5, 2021; Final acceptance in revised form: March 31, 2021

This paper was earlier presented at the International Conference on Energy, Environment \& Material Sciences (ICE2M), 1-3 December 2019 and substantially improved for this Special Issue. Guest Editor: Dr. Sri Niwas Singh, Professor (HAG), Department of Electrical Engineering, Indian Institute of Technology Kanpur, 208016 (U.P.) India, former Vice-Chancellor, Madan Mohan Malviya University of Technology Gorakhpur (April 2017 to July 2020 ).

\section{Introduction}

Today is very big problems to provide the safe drinking water for human being because of decline the water quality due to the threatening of the environment condition and generate waste water during the different activity in industries and society, merged in to ground water which causes of problems of the health issues in the world. Water also basic needs for the surviving in the world. Heavy metals also threaten to the health of the human beings. These also cause of the chronic disease Cancer and tumour. Heavy 
metals mainly found in earth crust and different segment of earth layer. The soluble heavy metal comes through seepage from the soil, Soil made of different type of minerals which are combined with organic and inorganic compound in nature (kumar et al., 2008).

Heavy metals like $\mathrm{Fe}, \mathrm{Mo}, \mathrm{Co}, \mathrm{Mn}, \mathrm{Cr}, \mathrm{As}, \mathrm{Ni}, \mathrm{Pb}, \mathrm{Zn}, \mathrm{Cd}, \mathrm{Hg}$ etc. Found in the food grains and water. They came in to water and food from the earth crust. Some metals as $\mathrm{Fe}, \mathrm{Mn}, \mathrm{Cr}, \mathrm{Mo}, \mathrm{Mg}$, Co are as nutrients for the body, it works as cofactor for metabolism of the cell in our body. Vegetables, cereals, milk and water are the energy source for human, having essential nutrients, anti-oxidants and required minerals. If lake of these essential nutrients and minerals in human beings cause of disturbance to function of the body (Snyder et al.,1984).

Many of the industries disposed its waste water it has the high amount heavy metals and other harmful chemicals and organic matter, disposed in to water resources without the treatment these heavy metals contamination seeps through earth crust in to the ground water. In south-western Punjab thermal energy power plant disposes wastes into the artificial pond hence water contaminated of this pond, contaminated water seeps through the bed of the pond, merged in to the ground water that also the causes of the heavy metals contaminated (cgwb, 2000). Heavy metals contaminated water use in irrigation purposes in farming of the crop they absorbed the heavy metals from the irrigated water that stored in the grains hence came in to the food chain these are the causes of spreads one tropic level to another level. These contaminated grain feed by human being, causes of adverse effect found in body human being. Heavy metals in vegetation and its seeds come from the untreated waste water used as irrigation purposes due to emphasment reuse of waste water and saving the water Earth crust also responsible for the heavy metal's contamination in to the ground water, $\mathrm{As}, \mathrm{Al}, \mathrm{Cr}, \mathrm{Ni}, \mathrm{Pb}$ etc. are geogenic metals. When water come in contact with the earth crust after rain fall these metals soluble in water by changing its oxidation state.

Mean concentration of all heavy metals in cereals and green vegetables compare with treated waste water used as irrigation in the field, found that the heavy metals in high amount in those cereals which nourishment with untreated water as comparison with the treated waste water for irrigation in the cultivation.

\section{Literature review}

Heavy metals concentration in milk found higher then prescribed limit by the WHO and Indian Standards. These heavy metals came in to the fodder from the soil, the cattle consume to it and after the metabolism process milk form hence these heavy metals dissolve. $\mathrm{Zn}$ found in highest amount then $\mathrm{Cu}>\mathrm{Pb}>\mathrm{Cr}>\mathrm{Ni}>\mathrm{Cd}$, if mother consumed heavy metals contaminated food and water, these contaminate transfer to the baby child from the mother through the milk feeding. It found in air, soil, and sea in the nature. Cadmium compounds are used in the manufacturing of batteries, pigments, paints, plastics and alloys etc., the discharge from these manufacturing industries pollutes the environment. Moreover, the mining activities also results in the contamination of the natural resources. According to IARC, it is found in tobacco and smoke of the cigarettes, inhalation of which results in the deposition in the lungs, resulting abnormality in the cell of lungs leading to cancer. It is kept in the Group 1 of the carcinogens classification (IARC). The contaminated cereals and vegetables consume by the consumer in the food chain in the different tropic level which caused transfer adverse effect of the heavy metals in each tropic level (Sinha et al. 2006). In Varanasi city of India, $\mathrm{Zn}, \mathrm{Pb}, \mathrm{Cd}, \mathrm{Cu}$ found in the vegetables and cereals of the selling market after the production (Sharma et al. 2009). When the present concentration of the metals found in the cereal and vegetation compared with the prescribed permissible limit by the difference regulate agencies such as WHO/Indian Standard. A co-relationship formed between concentration of heavy metals and metals having by the soil (Sinha et al. 2009).

Uranium concentration in the drinking water sample is in the range of 0.5 to $579 \mu \mathrm{g} / \mathrm{l}$, and $68 \%$ drinking water samples have average concentration 73.5 micro gram per litter (Bajwa et al., 2017; BARC, 2017). The rock of the S-W Punjab had large amount of Uranium. The leaching of the uranium into the ground water is the main reasons for uranium concentration in the ground water and is suspected to be one of the possible reasons of spreading cancer in the South-Western Punjab.

Polycyclic aromatic hydrocarbons are potentially carcinogenic, generally produced on incomplete combustion of crude oil, petroleum compounds, and organic compounds and during the manufacturing processes in the industries. Approximately, 100 polycyclic aromatic hydrocarbons are generated in the nature but most widely occurring carcinogenic compound in the nature is benzo-a-pyrene. These PAHs also finds application as a preservative for meat, fish fats, oils, and sweets. Benzo [a] pyrene is absorbed by the respiratory system of the human beings and can lead to cancer of lung and oral cancer to the human being (ATSDR, 2005)

Punjab has been the subject of much skepticism in the last decade. It has previously been called the "grain bowl of the country", but has recently adopted a new nickname, "the cancer bowl of the country". The pride of holding the title "a state with maximum per capita income" came with the price of cancer due to unrestricted use of chemicals (pesticides, fertilizers, metals, polycyclic aromatic hydrocarbons, pharmaceutically active hydrocarbons, etc.) in the agricultural fields and industries. A train which connects the affected region with the nearby Bikaner city, which contains a cancer hospital, has been nicknamed Cancer Express (Thakur et al., 2016). 


\section{Material and Methodes}

We collect the sample in the polyethylene bottle of $500 \mathrm{ml}$ volume, add the $2 \mathrm{ml}$ concentrate $\mathrm{HNO}_{3}$ for preservative to the metals and placed in ice box. Before collected the sample, some water falls out for 5 minutes from the hand pump or bore well. We have collected sample from the define location which shown in table 1.

Table 1. Details of sampling sites

\begin{tabular}{|c|l|l|l|}
\hline S.No. & Sampling location & Longitude (E) & Latitude (N) \\
\hline 1 & Pitho & $30.25094^{\circ}$ & $75.28457^{\circ}$ \\
\hline 2 & Lehra Mohabbat & $30.24499^{\circ}$ & $75.16401^{\circ}$ \\
\hline 3 & Mehma Sarja & $30.30200^{\circ}$ & $74.84476^{\circ}$ \\
\hline 4 & Rampura Paul & $30.26499^{\circ}$ & $75.23445^{\circ}$ \\
\hline 5 & Bambiha & $30.12956^{\circ}$ & $75.71142^{\circ}$ \\
\hline 6 & Hanuman Chowk & $30.21329^{\circ}$ & $74.94445^{\circ}$ \\
\hline 7 & JSW $^{\circ} 1$ & $30.13910^{\circ}$ & $74.86087^{\circ}$ \\
\hline 8 & JSW2 $^{\circ}$ & $30.13910^{\circ}$ & $74.86087^{\circ}$ \\
\hline 9 & Dhupali & $30.36291^{\circ}$ & $75.26682^{\circ}$ \\
\hline 10 & Bhai Rupa1 & $30.42879^{\circ}$ & $75.26682^{\circ}$ \\
\hline 11 & Bhai Rupa2 & $30.42879^{\circ}$ & $75.26682^{\circ}$ \\
\hline 12 & Dayalpur Mirza & $30.40415^{\circ}$ & $75.13204^{\circ}$ \\
\hline 13 & Mandi Kalan & $30.21212^{\circ}$ & $75.25963^{\circ}$ \\
\hline 14 & Nasibpura & $30.08812^{\circ}$ & $75.01995^{\circ}$ \\
\hline 15 & Gill Kalan & $30.27275^{\circ}$ & $75.27658^{\circ}$ \\
\hline 16 & Ganga & $30.33182^{\circ}$ & $75.07812^{\circ}$ \\
\hline 17 & Bathinda & $30.2144^{\circ}$ & $74.93299^{\circ}$ \\
\hline 18 & CUP** & $30.1714^{\circ}$ & $74.9659^{\circ}$ \\
\hline 19 & Nathana & $30.31686^{\circ}$ & $75.08968^{\circ}$ \\
\hline
\end{tabular}

Inductively Coupled Plasma Mass Spectrometry (ICP MS) - ICP MS is an analytical instrument which is used for measurement of the trace metals in the water. This instrument is highly advanced analytical instrument in modern time, with highest precision and accuracy and capability to measure the concentration of metals up to part per trillion (ppm) level. The ICP MS used for the detection of the carcinogenic heavy metals. The argon gas converts water sample into the mist or aerosol. At the high of the temperature $7000-10000 \mathrm{~K}$ and $27 \mathrm{MHz}$, plasma decomposed mist, and atomise and ionises the metal ions. The metal ions get separated from each other by electrostatic Quadruple, based on $\mathrm{m} / \mathrm{z}$ ratio. The ions are bombard on detector in serial, resulting in the generation of electronic signal specific to metal ion and a limb graph is generated. The area under the graph represents the concentration of metal in water. The high limb denotes high concentrate of element.

Procedure- firstly calibrates the instrument by the standard sample of $5 \mathrm{ml}, 50 \mathrm{ml}, 500 \mathrm{ml}$ of measured metals after then the inlet pipe dip into the Distilled water after sucking D W then the inlet pipe inserts in to water sample. Water sample convert into mist on contact with the argon gas in the nebuliser. The ICP Torch form coupled plasma of this mist reach in at $7000 \mathrm{~K}$ to $10000 \mathrm{~K}$. Mist decompose, atomise and ionise, the metallic ions separated from the neutral sepses by off axis lens. Collision between the Helium gas and metallic ions formed. the heavy metal pass, a ions series form by electrostatic Quadruple, hence the ions bombard on ions detector in serial hence a electronic signal generated corresponding to metallic ions and form a bar graph. the limb of graph represents the concentration of metal in water. concentrate beam, form a mass spectrum from the concentration of ions, this mass spectrum converts in a limb graph on computer screen. The high limb denoted high concentrate of element (APHA, 2005).

\section{Result and Discussion}

$4.1 \mathrm{pH}: \mathrm{pH}$ is one of the most important parameters in water chemistry. $\mathrm{pH}$ in the Ground water in South- Western Punjab found in the range of 6.6-7.4. The average value of $\mathrm{pH}$ is 6.9. As command, the highest value (7.4) was for the sample from Ganga village, and the lowest (6.65) was for Dayalpur Mirja Village. All these water samples contained pH well within the desirable limits prescribed by BIS (2012) [8] and WHO (2011) for various uses of water including drinking and other domestic supplies. The Ground Water of the all village of Bathinda district is drinkable in respect of $\mathrm{pH}$ prescribed by the IS $10500: 2012$ as shown in Figure 1. 


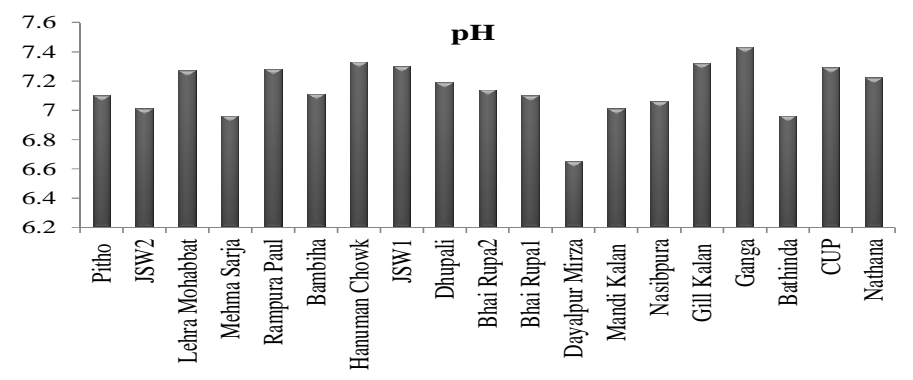

Figure 1. $p \mathrm{H}$ level in Bathinda of south-western region, Punjab, India

4.2 Electrical conductivity (EC): Indicates the ions (impurity) presence in the water hence it is depending on the ions concentration, ions mobilization depended on temperature. The electrical conductivity and dissolved salt concentrations are directly related to the concentration of ionized substance in water and may also be related to problems of excessive hardness and other mineral contamination. The overall range of the electrical conductivity varied between $177 \mu \mathrm{S} / \mathrm{cm}$ and $4300 \mu \mathrm{S} / \mathrm{cm}$ in all water samples (includes the sources such as hand pumps, tube wells, dug wells, water supply schemes). Minimum EC $177 \mu \mathrm{S} / \mathrm{cm}$ was observed for Dayalpur Mirja village and maximum EC $4300 \mu \mathrm{S} / \mathrm{cm}$ was observed for Jai Singh Wala in Bathinda District. The average $\mathrm{EC}$ is $1697.8 \mu \mathrm{S} / \mathrm{cm}$ as shown in Figure 2.

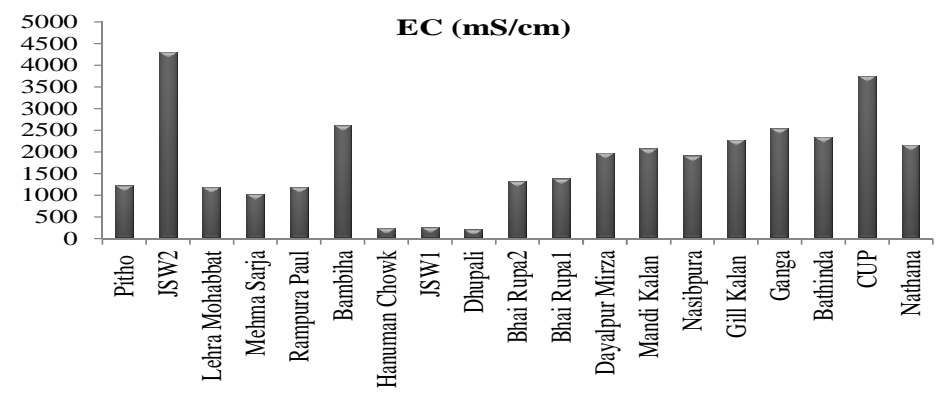

Figure 2. EC level in Bathinda of south-western region, Punjab, India

4.3 Chromium ( $\mathrm{Cr}$ ): Concentration of $\mathrm{Cr}$ in sampled water varies from 70 to $360 \mu \mathrm{g} / \mathrm{L}$, with maximum concentration in the groundwater of Lehra-mohbbat village. The average value of $\mathrm{Cr}$ is $90 \mu \mathrm{g} / \mathrm{L}$. IS 10500:2012 prescribed the acceptable limit of 50 $\mu \mathrm{g} / \mathrm{L}$ shown by red line in fig no. 3 for $\mathrm{Cr}$ in the drinking water and there is no relaxation in absence of alternate sources. All the analyzed water sample have the Cr content beyond the prescribed limit by BIS [8]. The carcinogenicity experiments on rats, results indicated no increase in tumor incidence the carcinogenicity of $\mathrm{Cr}$ (VI) is higher than $\mathrm{Cr}$ (III) and hence, to understand the extent of carcinogenicity speciation is required. Hence, ground water of the Bathinda district was affected by the Chromium carcinogenicity. Hence, the water is not suitable for drinking in Bathinda, in S-W Punjab. IARC experiment on the rat, not found any evidence of the cancer and tumour on given dose of Chromium (III) via orally and but some evidence of chromium (VI) carcinogenicity as shown in Figure 3.

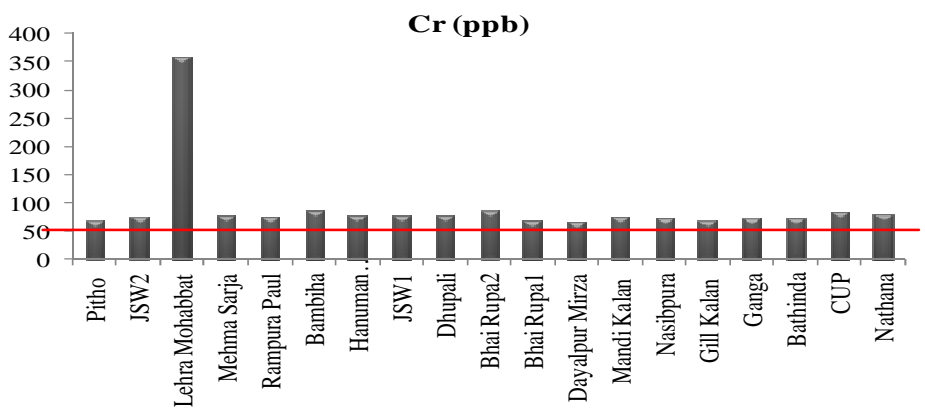

Figure 3. Cr level in Bathinda of south-western region, Punjab, India 
4.4 Mercury $(\mathrm{Hg})$ : The concentration of mercury in the collected water samples ranged from $4.6 \mu \mathrm{g} / \mathrm{L}$ to $20 \mu \mathrm{g} / \mathrm{L}$. Minimum concentration was observed in the samples from Nasibpura and maximum concentration was for the samples from Bambiha village of Bathinda district of S-W Punjab. The average value of Mercury $(\mathrm{Hg})$ in the samples was computed to be $10 \mu \mathrm{g} / \mathrm{L}$. The BIS 2012 [8] has recommended $1 \mu \mathrm{g} / \mathrm{L}$ as the permissible limit for drinking water . we measure the concentration of $\mathrm{Hg}$ in the water (drinking) sample from the study area contain $\mathrm{Hg}$ higher than the permissible limit (red line) as shown in Figure 4.

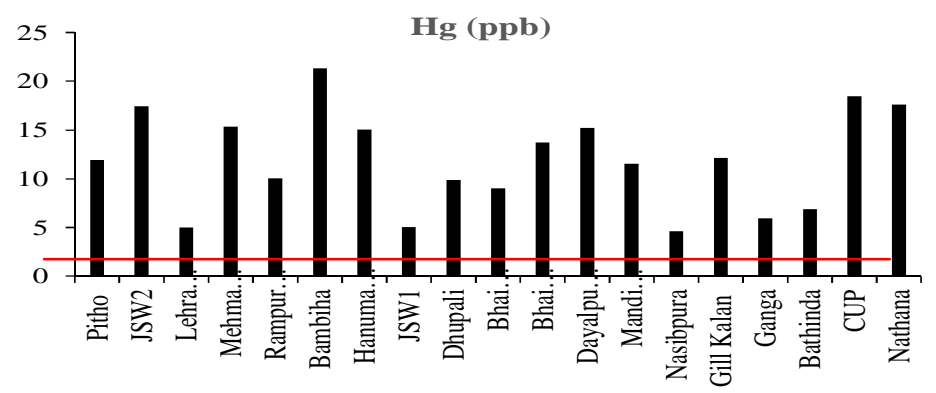

Figure 4. $\mathrm{Hg}$ level in Bathinda of south-western region, Punjab, India

4.5 Selenium ( $\mathrm{Se}$ ): Selenium (Se) concentration in the drinking water samples in Bathinda District was in the range of $2.315 \mu \mathrm{g} / \mathrm{L}$ to $17.583 \mu \mathrm{g} / \mathrm{L}$. The minimum concentration was observed in the sample from Jai Singh wala-1 village and maximum concentration was for Jai Singh Wala-2 village. The Bureau of Indian Standards (BIS2012) has recommended $10 \mu \mathrm{g} / \mathrm{L}$ as the acceptable limit and there is no relaxation for drinking water (BIS, 2012). The selenium concentration in $16 \%$ of the collected samples exceeded the limit for drinking water as shown in Figure 5.

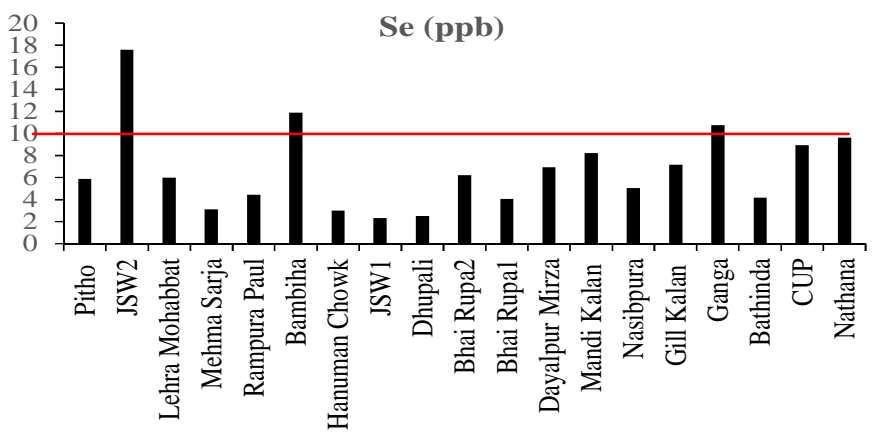

Figure 5. Se level in Bathinda of south-western region, Punjab, India

Selenium is an essential element for humans. According to Several studies proved that blood have Se, Se levels to be inversely associated with the prevalence of several types of cancer. Studies on urinary selenium levels indicated good correlation between gastrointestinal disturbances, decayed teeth, hair or nail loss, nail abnormalities, discoloration of the skin and changes in peripheral nerves, with high selenium concentration in urine.

4.6 Cadmium $(C d)$ : Cadmium $(\mathrm{Cd})$ concentration in the drinking water samples of the study area was in the range 0.117 to 2.99 $\mu \mathrm{g} / \mathrm{L}$. The average value of Cadmium (Cd) is $0.0 .597 \mu \mathrm{g} / \mathrm{L}$. Minimum concentration was observed for the sample from Bhai Rupa Village and maximum concentration was for the sample from the Central University of Punjab Campus. BIS (2012) has prescribed the limit of $3 \mu \mathrm{g} / \mathrm{L}$ for cadmium content in the drinking water, and all the samples except Central University of Punjab were well within the limits as shown in Figure 6. 


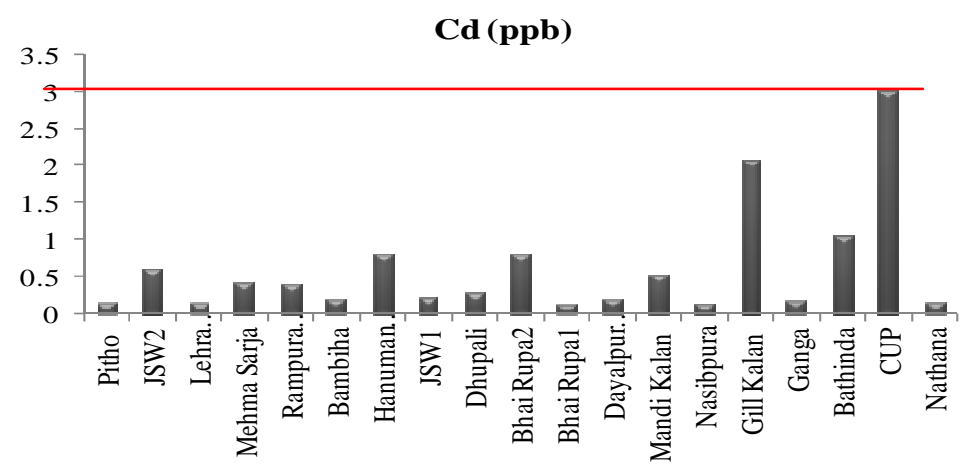

Figure 6. Cd level in Bathinda of south-western region, Punjab, India

4.7 Arsenic (As): The concentration of Arsenic in the ground water of the study area ranges from $0.81-2.912 \mu \mathrm{g} / \mathrm{L}$ as shown in. The Bureau of Indian Standards has recommended $10 \mu \mathrm{g} / \mathrm{L}$ as the desirable limit and $50 \mu \mathrm{g} / \mathrm{L}$ as the permissible limit for drinking water (BIS, 2012). As concentration in all the samples of the study area were within the recommended desirable limit as shown in Figure 7.

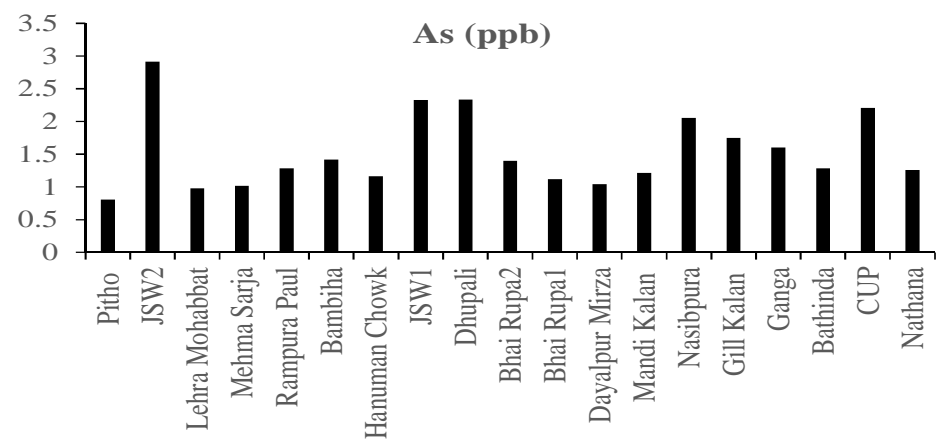

Figure 7. As level in Bathinda of south-western region, Punjab, India

\section{Conclusions}

In this study, the contamination of $\mathrm{Cr}, \mathrm{Hg}, \mathrm{Se}$, and $\mathrm{Cd}$ is mainly observed in the water sample taken from the different site of the study area. In all the 19 samples $\mathrm{Cr}$ and $\mathrm{Hg}$ are above the permissible limit of drinking water quality guideline of WHO and BIS [8]. Cr ranged from 70-360 ppb and the highest level of $\mathrm{Cr}$ was observed at Lehra Mahabbat and it was $360 \mathrm{ppb}$ which was 310 $\mathrm{ppb}$ above the permissible limit of drinking water. The permissible limit in the drinking of $\mathrm{Hg}$ is $1 \mathrm{ppb}$ and in all the sample the $\mathrm{Hg}$ concentration in all $100 \%$ of samples was above the safe drinking water level.

\section{Acknowledgement}

I would like to express my deep sense of gratitude and indebtedness to my supervisor Prof. Govind Pandey, Head of Civil Engineering Department, Madan Mohan Malaviya university of Technology, Gorakhpur and Dr. Rajesh Singh, Scientist "C", NIH, Roorkee, U.K., India.

\section{References}

Agency for Toxic Substances and Disease Registry (ATSDR) 2005 Top 20 Hazardous Substances: ATSDR/EPA Priority List for 2005

APHA (Clesceri L.S., Greenberg A.E., Trussel R.R., 2005) Standard Methods

BIS Indian Standard Drinking Water - Specification (Second Revision), IS:10500:2012, Bureau of Indian Standards, New Delhi CGWB and CPCB (2000) Status of Ground Water Quality and Pollution Aspects in NCT- Delhi, January 2000. IARC Report 
Kumar G., Kaur A., International Journal of Advanced Research in Management and Social Sciences: Punjab Central University of Punjab ISSN: 2278-6236

Singh, Lakhwant, Rajesh Kumar, Sanjeev Kumar, B. S. Bajwa, and Surinder Singh. 2013. "Health Risk Assessments Due to Uranium Contamination of Drinking Water in Bathinda Region, Punjab State, India." Radioprotection 48(2):191-202.

Snyder, C.A., Goldstein, B. D., Sellakumar, A.R. \& Albert, R.E. (1984) Evidence for hematotoxicity and tumorigenesis in rats exposed to 100 ppm benzene. Am. J. ind. Med., 5,429-434 17.

Thakur , T. , Madhuri S. R., Herojeet RK, and Renu L, Konchok D “Arsenic Contamination in Groundwater of Punjab State: An Overview” 2016, Environment: Traditional \& Scientific Research, Volume 1, Issue 1, Department of Environment Studies, Panjab University, Chandigarh, India

Toxicity, Human, and Toxicity Hazards. 2001. "Risk Assessment." 568-73.

Yadav, Poonam, Balvinder Singh, V. K. Garg, Suman Mor, and Vandana Pulhani. 2017. "Bioaccumulation and Health Risks of Heavy Metals Associated with Consumption of Rice Grains from Croplands in Northern India." Human and Ecological Risk Assessment 23(1):14-27. 